удк 351

DOI https://doi.org/10.32851/2708-0366/2020.4.4

Вольська О.М.

доктор наук з державного управління, доцент, профресор кафредри публічного управління та адміністрування, Херсонський державний аграрно-економічний університет ORCID: https://orcid.org/0000-0001-5047-4579

Ковпанець Є.M. студент, Херсонський державний аграрно-економічний університет ORCID: https://orcid.org/0000-0002-1405-1381

Volska Olena, Kovpanets Eugene Kherson State Agrarian and Economic University

\title{
УДОСКОНАЛЕННЯ ФІНАНСОВОЇ ДЕЦЕНТРАЛІЗАЦІЇ МІСЦЕВОГО САМОВРЯДУВАННЯ
}

\author{
IMPROVEMENT OF FINANCIAL DECENTRALIZATION \\ OF LOCAL GOVERNMENT
}

У статті розглянуто процес реформаиії крізь призму фінансів місиевого самоврядування в Україні. Розкрито підходи до з'ясування сутності та особливостей функціонування фінансової системи. Потреба в децентралізаиї, зокрема фінансовій, не викликає заперечень, оскільки лиме громадяни-власники можуть ефективно керувати значними ресурсами держави в інтересах громадськості. Головною перевагою децентралізації є залучення громадян до вирішення місцевих проблем шляхом створення об 'єднаних територіальних громад від формування місиевої влади, наділення ї̈ повноваженнями, прийняття плану стратегічного розвитку громади та здійснення контролю за діями влади відповідно до стратегічного плану. Фінансова децентралізаиія та самодостатність бюджетів територіальних громад є визначальними передумовами динамічного розвитку національної економіки, тому трансформація філософії бюджетної політики, податкової політики держави, методології та стратегії оптимізаиії місиевої податкової політики в Україні має бути спрямована на те, шоб територіальні громади завдяки власному розвитку сприяли надходженням до місиевого бюджету, зокрема податковим, які закріплені за місиевими бюджетами для забезпечення самоокупності та фінансування всіх видатків на території об'єднаної територіальної громади.

Ключові слова: децентралізація, територіальна громада, реформа місцевого самоврядування, місиеві бюджети, місцеві податки, фінансова децентралізація.

В статье рассмотрен процесс реформации сквозь призму финансов местного самоуправления в Украине. Раскрыты подходы к выяснению сущности и особенностей функиионирования финансовой системьл. Потребность в децентрализации, в частности финансовой, не вызывает возражений, поскольку только граждане-владельцьь могут эффективно управлять значительными ресурсами государства в интересах общественности. Главным преимуществвом децентрализации является привлечение граждан к решению местных проблем путем создания объединенных территориальных общин от формирования местной власти, наделения ее полномочиями, принятия плана стратегического развития общества и осушествления контроля над действиями власти в соответствии со стратегическим планом. Финансовая дечентрализация и самодостаточность бюджетов территориальных общин являются определяющими предпосылками динамичного развития начиональной экономики, поэтому трансформация философии бюджетной политики, налоговой политики государства, методологии и стратегии оптимизации местной налоговой политики в Украине долюнна быть направлена на то, чтобы территориальные общчины благодаря собственному развитию способствовали поступлениям в местный бюджет, в частности налоговым, которые закреплены на местными бюджетами для обеспечения самоокупаемости и финансирования всех расходов на территории объединенной территориальной общиныл.

Ключевые слова: децентрализация, территориальная общчина, реформа местного самоуправления, местные бюджеты, местные налоги, финансовая децентрализация. 
The article examines the reformation process through the prism of local government finance in Ukraine. The purpose of the article is to explore the directions of improving the financial decentralization of local self-government in modern conditions. A special place in these processes is given to the financial system of the country, where the financial resources of the country are formed, distributed and used. The financial system develops according to its rules developed over millennia, and its functioning is regulated by laws and various regulations. The main priorities of the financial system of Ukraine on socio-economic processes in society are to provide all subjects of financial relations with sufficient financial resources they need to fully perform their functions and tasks, ensure economic power, overcome poverty, improve welfare, and reduce unemployment. Economics considers the financial mechanism as a means of implementing the principles of financial policy of the state in all parts of the financial system through specific forms, methods, levers and tools. Features of the functioning of these components of the financial mechanism depend on the organization of financial relations in each link of the financial system. Approaches to the essence and features of the functioning of the financial system are disclosed. The need for decentralization, in particular financial, is not in doubt, since only citizens can effectively manage public resources. The main advantage of decentralization is the participation of citizens in solving local problems by creating united territorial communities, starting with the formation of local government, empowering it, adopting a plan for the strategic development of society and exercising control over the actions of the government, in accordance with the strategic plan. Financial decentralization and self-sufficiency of the budgets of territorial communities is a defining prerequisite for the dynamic development of the national economy. Therefore, financial decentralization in Ukraine should be aimed at replenishing local budgets, the costs of which should be aimed at solving local problems.

Key words: decentralization, territorial community, local government reform, local budgets, local taxes, financial decentralization.

Постановка проблеми. Трансформаційні процеси в Україні зумовлюють необхідність посилення впливу фінансових важелів та інструментів на функціонування економіки й соціальної сфери, що здійснюватиме прискорення темпів соціально-економічного розвитку суспільства та зростання добробуту громадян.

Особливе місце у цих процесах відведено фінансовій системі країни, де формуються, розподіляються та використовуються фінансові ресурси країни. Фінансова система розвивається за своїми правилами, напрацьованими упродовж тисячоліть, а ії функціонування регулюється законами та різними нормативними актами. Основними пріоритетами впливу фінансової системи України на соціально-економічні процеси у суспільстві є забезпечення всіх суб'єктів фінансових відносин достатнім обсягом фінансових ресурсів, які їм потрібні для повноцінного виконання своїх функцій i завдань, забезпечення економічної могутності країни, подолання бідності, покращення добробуту населення, зниження безробіття.

Реалізація цих та інших завдань вимагає подальшого розвитку фінансового механізму у кожній ланці фінансової системи, спрямування усіх складових частин фінансового механізму на досягнення високих результатів економічного зростання. Саме тому актуалізується доцільність поглиблення наукових досліджень 3 питань розвитку фінансового механізму в умовах реформування фінансової системи України.

Аналіз останніх досліджень і публікацій. Науково-методологічні підходи до визначення напрямів розвитку видів, форм, методів, інструментів та важелів фінансового механізму, їхнього впливу на якість функціонування фінансової системи України розробили такі українські вчені, як М. Артус, Л. Безгубенко, В. Базилевич, О. Василик, О. Долгальова, С. Мочерний, Ю. Кирилов, О. Кириленко, В. Коваленко, О. Коваленко, С. Ковальчук, О. Ковалюк, М. Крупка, В. Кудряшов, Д. Клиновий, І. Петровська, Л. Потравка, О. Романенко, В. Федосов, С. Юрій, П. Юхименко [2]. Напрями практичного використання складових частин фінансового механізму у процесі управління фінансовою системою держави визначені Бюджетним [1] та іншими кодексами України, законами України та іншими нормативними актами, серед яких особливе місце посідає Стратегія реформування системи управління державними фінансами [7]. 
Однак, незважаючи на великий науковий і практичний інтерес до питань ролі фінансового механізму у функціонуванні фінансової системи України, досі не сформовано комплексний підхід, який дасть змогу достовірно оцінити кількісні та якісні параметри впливу напрямів розвитку окремих складових частин фінансового механізму на процес реформування фінансової системи України й підвищення ефективності її функціонування.

Формулювання цілей статті. Метою статті є дослідження напрямів удосконалення фінансової децентралізації місцевого самоврядування у сучасних умовах.

Виклад основного матеріалу. Економічна наука розглядає фінансовий механізм як засіб реалізації засад фінансової політики держави в усіх ланках фінансової системи за допомогою специфічних форм, методів, важелів та інструментів. Особливості функціонування цих складових частин фінансового механізму залежать від організації фінансових відносин у кожній ланці фінансової системи [4, с. 142].

Фінансова система $є$ складовою частиною економічної системи суспільства й належить до систем інтеграційного типу, які можна характеризувати тісною взаємодією всіх тих елементів, що входять до неї у вигляді підсистем, а також тим, що жодна 3 цих підсистем не може існувати самостійно. Це обумовлено тим, що фінанси, з одного боку, відображають частину економічних відносин, тому є елементами економічної системи, а з іншого боку, являють собою самостійну специфічну систему, яка складається зі взаємопов'язаних елементів, що мають загальні функціональні властивості [2, с. 60]. Місце, роль і значення окремо взятих елементів фінансової системи різняться між собою. Так, наприклад, головний елемент посідає провідне місце серед інших елементів системи, оскільки його роль і місце серед усіх інших елементів $\mathrm{i}$ ланок системи $є$ визначальними. Таким елементом у фінансовій системі суспільства, без сумніву, є загальнодержавні фінанси, центральним елементом яких є державний бюджет.

Цей головний елемент тісно взаємодіє з усіма іншими елементами фінансової системи, які формуються під впливом первинного елементу та одночасно самі впливають на нього. Така взаємодія відбувається на основі тісних зв'язків елементів та їх ланок, які в ринковому суспільстві підпорядковуються законам ринкової економіки [5, с. 164].

Нині Україна проводить низку реформ, спрямованих на розширення повноважень територіальних громад, їх органів і посадових осіб місцевого самоврядування. Це сприятиме перетворенню централізації влади в державі на іiі децентралізацію (передання влади, повноважень, грошей, власності та відповідальності місцевим громадам та їх органам). Ускладнення фінансово-економічної ситуації в країні спричинено підвищенням повноважень громад у контексті формування та діяльності органів місцевого самоврядування, зокрема щодо створення місцевими жителями територіальних громад як суб'єктів господарювання, а також органів місцевої влади як структурних підрозділів цього суб'єкта господарювання [6, с. 26].

Варто зауважити, що фундаментальні зміни, що відбулися внаслідок проведення реформи, передбачали не лише значне збільшення обсягів ресурсів місцевого самоврядування та джерел їх надходжень, а передусім розвиток системи управління місцевими бюджетами. Нововведення насамперед стосуються розширення повноважень органів місцевого самоврядування у сфері управління місцевими фінансами, збільшення їх відповідальності перед громадами за виконання бюджетних програм та розвиток територій [3, с. 9]. Завдяки цьому особливої важливості набувають питання планування бюджетів на місцях, визначення довгострокових цілей розвитку та джерел їх забезпечення. Організація економічного розвитку та співробітництва (ОЕСР) надає такі рекомендації, що визначають підходи до планування місцевих бюджетів [6, с. 27]:

- тісне узгодження бюджетів зі стратегічними пріоритетами органів влади; 
- сприяння цілісності та якості бюджетних прогнозів, фіскальних планів та виконання бюджету через сувору гарантію якості, включаючи незалежний аудит;

- дотримання чітких, достовірних і передбачуваних обмежень фіскальної політики;

- розроблення структури інвестиційної складової частини бюджету, яка відповідає потребам розвитку;

- забезпечення відкритості, прозорості та доступності бюджетних документів і даних;

- забезпечення інклюзивних, активних і реалістичних дебатів щодо бюджету;

- створення умов, за яких невід'ємною частиною бюджетного процесу є оцінювання співвідношення ціни та якості.

Реформа децентралізації вийшла на такий етап, коли кількісні показники мають конвертуватися у нову якість, а саме нову якість надання послуг, нову якість життя. Реформа має просуватися вглиб, отже, основним іiї завданням є іiї секторальне просування в освіті, медицині, сфері безпеки, земельних відносинах.

Разом зі значними досягненнями у проведенні реформи досі залишається низка таких проблем, що гальмують процес децентралізації в Україні [8, с. 86]:

- відсутність системного зв'язку бюджетів ОТГ з комплексом пріоритетів соціально-економічного розвитку (у значної частини громад відсутні плани реалізацій цілей стратегічного розвитку, вони обмежуються виключно річними програмами соціально-економічного розвитку, на основі яких формуються бюджети [3, с. 12]);

- д дуже низький рівень залучення громадськості у бюджетний процес ОТГ (діалог між органами влади ОТГ і громадянами у сфері бюджетного планування нерідко дуже обмежений, зокрема через недосконалість інформування й недоліки консультування $[6$, c. 29]);

- неузгодженість між зобов'язаннями ОТГ за видатками та їх джерелами й обсягами фінансування (значна частина новостворених ОТГ досі залишається дотаційною через слабкий економічний розвиток певних територій i, відповідно, відсутність стабільних джерел бюджетних надходжень).

Потреба в децентралізації, зокрема фінансовій, не викликає заперечень, оскільки лише громадяни-власники можуть ефективно керувати значними ресурсами держави в інтересах громадськості. Головною перевагою децентралізації є залучення громадян до вирішення місцевих проблем шляхом створення об'єднаних територіальних громад від формування місцевої влади, наділення її повноваженнями, прийняття плану стратегічного розвитку громади та здійснення контролю за діями влади відповідно до стратегічного плану.

Усі питання місцевого значення слід вирішувати коштом місцевого бюджету 3 використанням трансфертів із центрального бюджету. 3 огляду на це завданням місцевої влади має бути самозабезпечення громад шляхом надходження доходів від експлуатації комунального майна та прибутку комунальних підприємств, а також місцевих податків. На нашу думку, це сприятиме послабленню податкового навантаження, трансформації в привабливішу підприємницьку екосистему, що створить нові бізнес-можливості для членів територіальних громад.

Питання про структуру й джерела доходів місцевого самоврядування, а також напрями бюджетних витрат слід вирішувати територіальним громадам шляхом прийняття та здійснення контролю за виконанням стратегічного плану розвитку громади. 3 огляду на це всі питання місцевого значення, тобто питання розвитку та життєзабезпечення місцевих громад, є насамперед обов'язком громади.

Висновки. Фінансова децентралізація та самодостатність бюджетів територіальних громад $є$ визначальними передумовами динамічного розвитку національної економіки, тому трансформація філософії бюджетної політики, податкової політики 
держави, методології та стратегії оптимізації місцевої податкової політики в Україні має бути спрямована на те, щоб територіальні громади завдяки власному розвитку сприяли надходженням до місцевого бюджету, зокрема податковим, які закріплені за місцевими бюджетами для забезпечення самоокупності та фінансування всіх видатків на території об'єднаної територіальної громади.

\section{Список використаних джерел:}

1. Бюджетний кодекс України : Кодекс України ; Закон, Кодекс від 8 липня 2010 року № 2456-VI. URL: https://zakon.rada.gov.ua/laws/show/2456-17\#Text (дата звернення: 01.11.2020).

2. Дем'янишин В., Лободіна 3. Розвиток фінансового механізму в умовах реформування фінансової системи України. Формування ринкової економіки в Україні. 2020. Вип. 43. С. 59-80.

3. Кнейслер О., Спасів Н., Кізима Т. Фінанси об'єднаних територіальних громад у фінансовій системі України. Світ фінансів. 2020. № 1 (62). С. 8-19.

4. Малахов М. Моніторинг місцевих податків і зборів до місцевих бюджетів України. Сучасний стан та перспективи розвитку фінансової системи Украйни : збірник наукових праць IX Всеукраїнської науково-практичної інтернет-конференції. Вінниця : Редакційно-видавничий відділ ВТЕІ КНТЕУ, 2020. С. 142-148.

5. Матвієнко Є. Формування місцевих бюджетів як фінансової бази місцевого самоврядування. Науково-практичне забезпечення надання публічних послуг в умовах децентралізачії : збірник матеріалів доповідей та тез III Всеукраїнської інтернет-конференції, Київ, 15 квітня 2020 року / заг. ред. Р. Войтович, П. Ворона. Київ : ТОВ Видавничий дім «АртЕк», 2020. С. 163-165.

6. Моргун В. Удосконалення фінансової основи місцевого самоврядування в контексті децентралізації, реалізації бюджетної та податкової політики держави. Юридичний часопис Національної академії внутрімніх справ. 2020. Т. 19. № 1. С. 25-32.

7. Про схвалення Стратегії реформування системи управління державними фінансами на 2017-2020 роки : Розпорядження Кабінету Міністрів України ; Стратегія від 8 лютого 2017 року № 142-p. URL: https://zakon.rada.gov.ua/laws/show/142-2017-p\#Text (дата звернення: 01.11.2020).

8. Степанюк А. Роль фінансової децентралізації в управлінні системою фінансів місцевого самоврядування. Інвестиції: практика та досвід. 2020. № 3. С. 83-87.

9. Kyrylov Y., Yarovoy V. State regulation and support of tourism services in the rural regions in accordance with European requirements. Baltic Journal of Economic Studies. 2018. V. 4 No. 4. P. 188-193.

10. Потравка Л. Синергетична парадигма публічного управління. Глобальні та національні проблеми економіки. 2018. № 22. URL: http://global-national.in.ua/issueve-22-2018 (дата звернення: 01.11.2020).

11. Долгальова O. The scientific basis for the sustainable development of regional economy. $\Phi i-$ нансово-кредитна діяльність: проблеми теорії та практики. 2018. Вип. 1 (24). С. 353-360.

\section{References:}

1. Biudzhetnyj kodeks Ukrainy : Kodeks Ukrainy; [Budget Code of Ukraine: Code of Ukraine] Zakon, Kodeks vid 08.07.2010 № 2456-VI. Available at: https://zakon.rada.gov.ua/laws/ show/2456-17\#Text (accessed 01 November 2020).

2. Dem'ianyshyn V., Lobodina Z. (2020) Rozvytok finansovoho mekhanizmu v umovakh reformuvannia finansovoi systemy Ukrainy [Development of the financial mechanism in the minds of the reform of the financial system of Ukraine]. Formuvannia rynkovoi ekonomiky v Ukraini. vol. 43, pp. 59-80.

3. Knejsler O., Spasiv N., Kizyma T. (2020) Finansy ob'iednanykh terytorial'nykh hromad u finansovij systemi Ukrainy [Finance about the same territorial communities at the financial system of Ukraine]. Svit finansiv. no. 1 (62), pp. 8-19.

4. Malakhov M. (2020) Monitorynh mistsevykh podatkiv i zboriv do mistsevykh biudzhetiv Ukrainy [Monitoring of monthly taxes and payments to the budget of Ukraine]. Suchasnyj stan ta perspektyvy rozvytku finansovoi systemy Ukrainy: zbirnyk naukovykh prats' IX Vseukrains'koi naukovo-praktychnoi Internet-konferentsii. Vinnytsia: Redaktsijno-vydavnychyj viddil VTEI KNTEU. Pp. 142-148.

5. Matviienko Ye. (2020) Formuvannia mistsevykh biudzhetiv iak finansovoi bazy mistsevoho samovriaduvannia [Formation of mice budgets as a financial basis of mice samovryvannya]. Procee- 
dings of the III Vseukrainska internetkonferentsiya (Ukraine, Kyiv, 15 April,2020) (eds. Vojtovych R., Vorony P.). Kyiv: TOV Vydavnychyj dim “ArtEk”, pp. 163-165.

6. Morhun V. (2020) Udoskonalennia finansovoi osnovy mistsevoho samovriaduvannia v konteksti detsentralizatsii, realizatsii biudzhetnoi ta podatkovoi polityky derzhavy [Adequate financial basis of micro-self-production in the context of decentralization, implementation of the budgetary and tax policy of the state]. Yurydychnyj chasopys Natsional'noi akademii vnutrishnikh sprav, vol. 19, no. 1, pp. 25-32.

7. Pro skhvalennia Stratehii reformuvannia systemy upravlinnia derzhavnymy finansamy na 2017-2020 roky: Rozporiadzhennia Kabinetu Ministriv Ukrainy; [About the Strategy Reform of the System and Management of State Finances for 2017-2020 Rocks: Order of the Cabinet of the Ministry of Finance of Ukraine]. Stratehiia vid 08.02.2017 № 142-r. Available at: https://zakon.rada.gov.ua/ laws/show/142-2017-r\#Text (accessed 01 November 2020).

8. Stepaniuk A. (2020) Rol' finansovoi detsentralizatsii v upravlinni systemoiu finansiv mistsevoho samovriaduvannia [The role of financial decentralization in the management of the financial system of micro-self-assembly]. Investytsii: praktyka ta dosvid, no. 3, pp. 83-87.

9. Kyrylov Y., Yarovoy V. (2018) State regulation and support of tourism services in the rural regions in accordance with European requirements. Baltic Journal of Economic Studies, vol. 4, no. 4, pp. $188-193$.

10. Potravka L. (2018) Cynerhetychna paradyhma publichnoho upravlinnia [The synergetic paradigm of public administration]. Hlobal'ni ta natsional'ni problemy ekonomiky, no. 22. Available at: http://global-national.in.ua/issueve-22-2018 Text (accessed 01 November 2020).

11. Dolhal'ova O. (2018) The scientific basis for the sustainable development of regional economy. Finansovo-kredytna diial'nist': problemy teorii ta praktyky, vol. 1 (24), pp. 353-360. 